\title{
Sleeping distance in relation to sexual state in the Arctic blue fox
}

\author{
H Korhonen ${ }^{1, *}$, S Alasuutari 2
}

\author{
1 Fur Farming Research Station, Agricultural Research Centre of Finland, SF-69100 Kannus; \\ ${ }_{2}^{2}$ Muddusjäni Experimental Farm, University of Helsinki, SF-99910 Kaamanen, Finland
}

(Received 22 October 1991; accepted 7 February 1992)

\begin{abstract}
Summary - The paper provides comparative data concerning sleeping distance in relation to sexual state and hierarchical dominance in the Arctic blue fox. Increasing levels of vulval swelling and electrical resistance of vaginal tract were inversely related to sleeping distance between the highestranking male and each female on heat. A mating pair typically slept no further than $50 \mathrm{~cm}$ from each other. One month after copulation, the distance was already more than $200-250 \mathrm{~cm}$. It can be concluded that oestrus-associated changes in sexual hormone levels have an influence on observed changes in sleeping distance.
\end{abstract}

sleeping distance / sexual state / social status / Alopes lagopus = Arctic blue fox

Résumé - Distance de repos et statut de reproduction chez le renard bleu. Ce travail présente des résultats comparatifs sur la distance de repos entre le mâle dominant et les femelles d'un groupe de 6 renards arctiques (Alopex lagopus, 3 mâles et 3 femelles) en relation avec l'état de réceptivité sexuelle des femelles. Le gonflement de la vulve et la résistance électrique vaginale des renardes sont inversement reliés à la distance de repos entre le mâle dominant et chaque femelle en chaleurs. Les 2 membres d'un couple dont la femelle est en chaleurs ne dorment pas à plus de $50 \mathrm{~cm}$ l'un de l'autre. Un mois après l'accouplement, la distance de repos entre les mêmes animaux est de plus de 200-250 cm. Ceci suggère que les changements des hormones sexuelles, associés à la période d'cestrus, ont une influence sur les variations de distance de repos observées entre le mâle dominant et les femelles dans un groupe de renards arctiques.

distance de repos / cestrus / hiérachie sociale /Alopes lagopus = renard arctique

* Correspondence and reprints 


\section{INTRODUCTION}

The Arctic fox (Alopex lagopus $\mathrm{L}$ ) is a thick-furred canid that mainly inhabits circumpolar regions of the northern hemisphere. Although the Arctic fox had previously been considered to be a rather solitary animal (Fox, 1969; Banfield, 1977), it was subsequently observed that it could also live in social groups (Hersteinsson and MacDonald, 1982; Garrett et al, 1984). Studies in captivity have additionally shown that, if housed in groups, this species can form social hierarchies and dominances which are supported by a rich repertoire of visual status signals (Wakely and Mallory, 1988; Korhonen and Alasuutari, 1991).

Numerous physiological and behavioural changes occur in relation to the breeding season. In dog-like canids such as the wolf, it has been observed that sleeping distance may be inversely related to female estrogen levels, which increase during proestrus, peak just before estrus, and drop sharply during estrus (Mech and Knick, 1978). Rising progesterone levels during estrus could then counteract the estrogen effect (Ulrings et al, 1987) thereby increasing sleeping distance.

The present study aims to provide comparative data on sleeping distance in relation to the sexual state and social status of Arctic blue foxes housed in a semi-natural enclosure.

\section{MATEFIALS AND METHODS}

\section{General procedures}

The experiments were carried out at the Muddusjärvi Experimental Farm in Finnish Lapland (69 04' N, 27 05' E). The group consisted of yearling (born May 24th, 1991) Arctic blue foxes (3 males, 3 females). After September, they were housed in a large ground floor enclosure measuring $17 \mathrm{~m}$ long $\times 8 \mathrm{~m}$ wide $\times 2 \mathrm{~m}$ high. A standard diet of fresh feed was provided daily (Korhonen and Harri, 1986). The animals were inspected daily and weighed 3 times during the experimental period.

\section{Estimation of hierarchical dominance}

The hierarchical dominance of the animals was estimated: 1), during feeding times when the animals competed for feed. Specifically, the order in which individuals ate as well as the number and outcome of challenges made by other foxes were monitored (Wakely and Mallory, 1988). The behaviour of both challengers and defenders was recorded; 2), during 24-hour consecutive observations when the hierarchical position of the animals could be determined from their visual status signals, scent markings and other related behaviour.

\section{Monitoring of estrus and grouping}

The development of the estrus cycle was carefully monitored in the females by evaluation of vulval swelling and change in electrical resistance of the vaginal tract (Möller, 1980). Electrical resistance was measured daily with a modified ohmmeter (SiLi3 digital heat detector, Lima AS, Sandnes, Norway). Mating activity and copulation were followed by direct observation during the breeding season.

The distances between groups were estimated in diameters of curled up sleeping foxes, which we measured to be $45 \mathrm{~cm}$. Individuals that slept more than $3 \mathrm{~m}$ apart were considered to be separate.

The results are expressed as mean \pm SD. The data were statistically treated by analysis of variance and Student's t-test using the SAS program (SAS Institute Inc, Cary, NC, USA).

\section{RESULTS}

The males dominated the females, and the entire group was characterized by a linear 
hierarchical structure, ie there were dominant, subdominant and subordinate individuals among both sexes. Hierarchical dominance was normally most pronounced during feeding times, especially during the breeding season. The highest-ranking or alpha male dominated all the other individuals. During the breeding season, the alpha male maintained a constant watch over the less dominant males, frequently chasing them away from the females. Fights and aggression were also evident in such cases.

Body weights of the animals averaged before (mid-January), at (mid-March) and after (mid-April) the breeding season $7.6 \pm$ $0.2 \mathrm{~kg}, 6.5 \pm 0.4 \mathrm{~kg}$ and $5.9 \pm 0.5 \mathrm{~kg}$, respectively.
The estrus of different females was not synchronized, but they came on heat at intervals of about a week from one another. Mean duration of actual estrus was 2 days. The first signs of vulval swelling were observed 11-14 days before copulation. After that, levels of vulval swelling increased and the first measured values for electrical resistance of the vaginal tract were obtained 5 days before copulation (table I). At this time, it was clearly established that the sexual state of the females was related to sleeping distance and grouping with the atpha male, which carefully controlled the distance. Sleeping distance estimated 6466 days before copulation was significantly greater $(P<0.001)$ than that observed $1-5$ days before. Each female on heat typically

Table l. Changes in vulval swelling and electrical resistance of vaginal tract in Arctic blue fox females in relation to sleeping distance with the alpha male before, during and after the breeding season.

\begin{tabular}{|c|c|c|c|c|}
\hline $\begin{array}{l}\text { Days to } \\
\text { copulation }\end{array}$ & $\begin{array}{c}\text { Sleeping } \\
\text { distance }(\mathrm{cm})\end{array}$ & $\mathbf{N}$ & $\begin{array}{l}\text { Electrical resistance } \\
\text { of vaginal tract }(\Omega)\end{array}$ & $\begin{array}{l}\text { Vulval } \\
\text { swelling }\end{array}$ \\
\hline
\end{tabular}

$\begin{array}{lrrcc}-66 & 240 \pm 15 & 8 & - & - \\ -65 & 210 \pm 25 & 6 & - & - \\ -64 & 220 \pm 25 & 9 & - & - \\ -5 & 40 \pm 10 & 9 & 105 \pm 10 & X \\ -4 & 45 \pm 15 & 9 & 120 \pm 25 & X \\ -3 & 40 \pm 10 & 3 & 210 \pm 55 & X X \\ -2 & 35 \pm 10 & 11 & 365 \pm 70 & X X X \\ -1 & 20 \pm 10 & 5 & 330 \pm 45 & X X X\end{array}$

Copulation

\begin{tabular}{rrrcc}
+1 & $90 \pm 20$ & 11 & $125 \pm 20$ & $X$ \\
+2 & $70 \pm 20$ & 3 & $115 \pm 25$ & X \\
+3 & $150 \pm 40$ & 11 & - & - \\
+4 & $180 \pm 50$ & 7 & - & - \\
+29 & $210 \pm 40$ & 5 & - & - \\
+31 & $270 \pm 45$ & 3 & - & - \\
\hline
\end{tabular}

The results are expressed as means $\pm S D ; N=$ number of observations. $X, X X$ and $X X X$ indicate the increasing amounts of vulval swelling. 
slept closer than $50 \mathrm{~cm}$ from the alpha male. Also when awake and in movement, they always stayed close to each other. As a result of their manifest submissiveness and lower rank, the other males were forced to keep at a distance of over $3 \mathrm{~m}$ from the nuclear group.

After copulation, the interest of the alpha male in a specific female rapidly decreased and was reflected in the sleeping distance. As early as 1-2 days later the alpha male clearly avoided the female in question, and this behaviour increased significantly $(P<0.01)$ as time progressed. About one month after copulation, the nuclear group typically slept more than 200$250 \mathrm{~cm}$ apart from each other, a distance which was not significantly different $(P>$ 0.05 ) from that observed 2 months before the estrus period.

\section{DISCUSSION}

The Arctic blue fox is a seasonally monoestrous species; proestrus normally does not last more than 12-24 days, while the actual estrus occurs during a period of 2-7 days (Einarsson and Skrede, 1989). Estrogen levels increase from the start of proestrus, and peak about 4-5 days before copulation (cf Jalkanen et al, 1988). Soon thereafter the levels of $\mathrm{LH}$ are at their highest while those of estrogen rapidly decline. Ovulation thus occurs a few days before actual copulation. Furthermore, the relationship between estrus cycle, vulval swelling and electrical resistance of the vaginal tract has been well documented (Möller, 1984; Jalkanen et al, 1988). Electrical resistance is normally measurable $4-8$ days before copulation, reaching the highest values just after ovulation.

As table I shows, our data on sleeping distances during the breeding season focus on the 4-5-day period before and after copulation. Thus, estrogen levels before copulation would have just reached their maximum and would have started to decrease. During this period, the alpha male and the female on heat were constantly in close contact, as also seen in their close sleeping distance. After copulation, progesterone levels increase significantly (Urlings et al, 1987; Jalkanen et al, 1988). At that stage, sleeping distance was also observed to increase. In the wolf, it has been speculated that such a rise in progesterone level, as well as changes in estrogen, may play a role in changes in sleeping distance (Mech and Knick, 1978). Such a hypothesis is valid in the Arctic blue fox, at least to some extent, as also indicated by our results. As concerns the days prior to copulation, however, it is probable that other factors (eg increased daylight and temperature, melatonin) besides estrogen hormone activate males, because males remain interested in females throughout the proestrus and estrus cycle despite increasing and decreasing levels of the estrogen hormone (cf Jalkanen et al, 1988).

\section{ACKNOWLEDGMENTS}

The authors would like to thank the staff of Muddusjärvi Experimental Farm for helpful cooperation and excellent working facilities. Financial support for this investigation was provided by the University of Helsinki and by the Agricultural Research Centre of Finland.

\section{REFERENCES}

Banfield AW (1977) The Mammals of Canada. University of Toronto Press, Toronto

Einarsson EJ, Skrede A (1989) Breeding and Feeding of Fox. Landbruksforlaget, Norway (in Norwegian)

Fox MW (1969) The anatomy of aggression and its ritualization in Canidae: a developmental 
and comparative study. Behaviour 35, 242258

Garrett RA, Eberhardt LE, Hanson WC (1984) Arctic fox denning behaviour in north Alaska. Can J Zool 62, 1636-1640

Hersteinsson P, MacDonald DW (1982) Some comparisons between red and arctic foxes, Vulpes vulpes and Alopex lagopus, as revealed by radiotracking. Symp Zool Soc Lond 49, 259-289

Jalkanen L, Valtonen M, Lukola A (1988) Electrical resistance and cytology of the vaginal tract in relation to ovarian hormone levels in the silver fox during estrus. In: Biology, Pathology and Genetics of Fur-Bearing Animals. Proc IVth Int Congr Fur Anim Prod (Murphy BD, Hunter DB, eds) Ontario, Canada, 5-G

Korhonen $H$, Harri M (1986) Effects of feeding frequency and intensity on growth, body composition, organ scaling and fur quality of farmed raccoon dogs. Acta Agric Scand 36, 410-420
Korhonen H, Alasuutari S (1991) Features of social behaviour in an Arctic fox group housed in a large enclosure. Scientifur 15, 201-210

Mech LD, Knick ST (1978) Sleeping distance in wolf pairs in relation to the breeding season. Behav Biol 23, 521-525

Möller OM (1980) Measurement of electrical resistance of the vaginal tract to determine the optimum time to mate blue fox, silver fox and raccoon dog. Norsk Pelsdyrblad 54, 591-595

Möller OM (1984) Siniketun kiiman mittaaminen ja oikea paritusajankohta. Turkistalous 56, 139-142

Ulrings $H$, van Beek $P$, van der Heijden JF (1987) Plasma progesterone-assay, a practical method for ovulation detection in blue fox (Alopex lagopus). Scientifur 11, 36-39

Wakely LG, Mallory FF (1988) Hierarchical development, agonistic behaviours, and growth rates in captive Arctic fox. Can J Zool 66, 1672-1678 